NAMA : Gamos Cristo S

NIM : 312020165

\title{
Tugas MKU Bahasa Indonesia
}

\section{1.a. Contoh Paragraf Tidak Efektif}

Budi adalah seorang pria sangat tampan sekali, ganteng dan menawan. Ia sangat di gemari di kelasnya. Budi juga merupakan anak paling diteladani di sekolah maka ia sangat di sayangi oleh orang tunya. Ia setiap hari pergi makan dan mandi pada jam 5 pagi. Sudah menjadi kebiasaanya untuk selalu belajar dan dikembangkan bakatnya.

\section{1.b. Menjadi Paragraf Efektif}

Budi adalah pria yang tampan. Ia sangat digemari di kelasnya. Budi juga merupakan anak paling teladan di sekolah ia sangat disayangi oleh orangtunya.Ia setiap hari pergi untuk makan dan mandi pada jam 5 pagi. Kebiasaannya belajar dan mengembangkan bakatnya

\section{Berikut beberapa paragraf yang tidak efektif dan tata tulis yang kurang tepat, tolong dikoreksi/disunting agar menjadi paragraf efektif dan tata tulis yang tepat.}

1. Saya ini adalah mahasiswa Universitas Kristen Satya Wacana, kebetulan saya berasal dari Semarang. Jadi untuk pergi kekuliah saya harus menggunakan transportasi umum yaitu, bus. Selain saya, banyak juga para mahasiswa UKSW yang tinggal diluar Salatiga yang menggunakan fasilitas kendaraan umum sebagai sarana transportasi.

*. Saya adalah mahasiswa Universitas Kristen Satya Wacana. Saya berasal dari Semarang. Untuk pergi kuliah, saya menggunakan transportasi umum yaitu, bus. Selain saya, banyak mahasiswa UKSW yang tinggal diluar Salatiga menggunakan fasilitas kendaraan umum sebagai saranatransportas

2. Verdy pergi ke bioskop karena ingin menonton film Joker, padahal novel Joker sudah pernah Verdy baca tetapi Verdy tetap ingin menonton film tersebut. Verdy pun ikut mengantri membeli tiket bersama teman-temannya, maka dia ikut berdesak-desakan dengan para pengunjung yang lain. Setelah mendapatkan tiket, Verdy dapat menoton film Joker yang sangat dia dambakan. Namun setelah selesai menonton Verdy di sadari bahwa film dan novelnya sangat berbeda. Menurut Verdy, novel Joker lebih bagus dari pada filmnya

*. Verdy pergi ke bioskop karena ingin menonton film Joker,padahal Verdy sudah pernah membaca novel Joker tetapi Verdy tetap ingin menonton film tersebut. Verdy pun ikut mengantri tiket bersama temannya, dia ikut berdesak-desakan dengan pengunjung yang lain. Setelah mendapatkan tiket Verdy dapat menonton film Joker yang sangat Dia dambakan. Namun setelah menonton film tersebut Verdy menyadari bahwa film dan novelnya sangat berbeda. Menurut Verdy,Novel Joker lebih bagus dari pada filmnya. 
3. Faktor risiko lain yang menjadi penyebab kejadian asma adalah allergen (serbuk bunga,tungau, serpihan atau kotoran binatang dan jamur), perubahan cuaca dan suhu udara, polusi udara, asap rokok, infeksi saluran pernapasan, stres, dan olahraga yang berlebihan.

*. Faktor lain yang menjadi penyebab terjadinya asma adalah Allergen( serbuk bunga, tungau, serpihan atau kotoran binatang dan jamur), perubahan cuaca dan suhu udara, polusi udara, asap rokok, infeksi saluran pernapasan, stress,dan olahraga yang terlalu berlebihan.

4. Masalah kelautan yang di hadapi dewasa ini ialah tidak adanya peminat atau penggemar jenis binatang laut seperti halnya peminat atau penggemar penghuni darat atau burung-burung yang indah. Tidak adanya penyediaan dana untuk melindungi ketam kenari, kima, atau tiram mutiara sebagaimana halnya untuk panda dan harimau. Jenis-jenis mahkluk laut tertentu tiba-tiba punah sebelum manusia sempat melindunginya. Tiram raksasa di kawasan Indonesia bagian barat kebanyakan sudah punah. Sangat sukar sekali menemukan tiram hidup dewasa ini, padahal rumah tiram yang sudah mati mudah ditemukan. Demikian juga halnya dengan kepiting kelapa dan kepiting begal yang biasa menyebar dari pantai barat Afrika sampai bagian barat Lautan Teduh, kini hanya di jumpai di daerah kecil yang terpencil. Dari mana diperoleh dana untuk melindungi semua ini?

*. Masalah kelautan yang saat ini sedang di hadapi ialah tidak adanya peminat atau penggemar jenis binatang laut, seperti halnya dengan peminat atau penggemar hewan darat atau burung - burung. Tidak ada penyediaan dana untuk melindungi Ketam Kenari, Kima, atau Tiram Mutiara sebagaimana halnya untuk Panda dan Hrimau. Jenis - jenis hewan laut tertentu punah sebelum manusia sempat untuk melindunginya. Tiram raksasa pada kawasan Indonesia bagian barat kebanyakan sudah punah. Sangat sulit sekali untuk menemukan Tiram yang hidup, padahal rumah Tiram yang sudah mati sangat mudah untuk di temukan. Demikian juga halnya dengan Kepiting Kelapa dan Kepiting Begal yang dapat menyebar dari Pantai Barat Afrika sampai bagian Barat Lutan Teduh, kini Kepiting tersebut hanya dapat di jumpai di daerah terpencil. Dari mana dana yang diperoleh untuk melindungi hewan yang sudah punah?

5. (1) Perbankan Indonesia telah mengalami perubahan orientasi sejak terjadi deregulasi keuangan Di Indonesia. Sebelum tahun 1980-an, bank-bank masih merupakan lembaga yang berorientasi pada produk. Masyarakat yang membutuhkan pelayanan bank akan datang dan mencari bank. Berbeda dengan kondisi setelah tahun 1983, bank telah tumbuh spektakuler baik menyangkut jumlah bank maupun jumlah produk / jasa yang ditawarkan ditunjang pelayanan yang modern. Persaingan antar bank menjadi semakin tajam baik pada level inovasi produk, level bunga maupun level pelayanan. Jadi pelayanan sempurna, bahkan super sempurna menjadi keharusan bagi bank untuk memenangkan persaingan. Selain itu, bank juga harus menggeser orientasi produk ke orientasi nasabah. 
(2) Sampah plastik merupakan salah satu sampah yang mencemari laut. Hal ini dibuktikan dari beberapa sumber yang mengatakan bahwa 90\% sampah yang mencemari laut adalah sampah plastik. Hal ini mengakibatkan sejumlah burung laut dan mamalia laut mengalami kematian. Oleh karenanya, penggunaan plastik mesti dikurangi agar tidak menambah jumlah sampah plastik yang akan mencemari permukaan laut

(3) Kesehatan adalah hal yang paling berharga. Tanpa kesehatan, manusia akan sangat kesulitan. Meskipun kita memiliki uang yang banyak, semua itu tidak ada gunanya jika kita sedang sakit. Bahkan orang - orang rela untuk menukar segala harta benda yang dimilikinya agar menjadi sehat kembali. Kesehatan menjadi sangat berharg karena biayanya yang mahal. Bahkan muncul pernyataan di masyarakat seperti "sehat itu mahal", "orang miskin tidak boleh sakit", . Meskipun pemerintah telah mengadakan program BPJS, Askes, dan lain - lain, tetap saja tidak bisa membuat kesehatan menjadi murah. Hal ini sangatlah wajar karena harga obat - obatan yang beredar sangatlah mahal, dan juga biaya untuk menjadi seorang dokter atau perawat sangat mahal. Semua biaya - biaya tersebut pada akhirnya dibebankan kepada pasien sehingga biaya pengobatan menjadi sangat mahal. 